Jurnal Ekonomi \& Studi Pembangunan

Volume 19, Nomor 1, April 2018, hlm. 21-34

DOI: 10.18196/jesp.19.1.3938

\title{
PENENTUAN POTENSI SEKTOR UNGGULAN DAN POTENSIAL DI PROVINSI MALUKU
}

\author{
Bayu Kharisma, Ferry Hadiyanto \\ Departemen Ilmu Ekonomi, Fakultas Ekonomi dan Bisnis, Universitas Padjadjaran \\ Jl. Dipati Ukur No. 35 Bandung, 40132, Indonesia \\ E-mail Korespondensi: bayu.karisma@fe.unpad.ac.id
}

\begin{abstract}
This paper aims to analyze the potentials of the leading sector and to formulate policy priorities for regional economic development in Maluku Province. The research methodology used in this research is Location Quotient (LQ), Growth Ratio Model (MRP) and Overlay analysis. The result of the research shows that in Maluku Province there are 8 economic categories that have basic sector namely agriculture, forestry and fishery category; categories of water supply, waste management and recycling; major trade-retail and auto-motorcycle repair categories; categories of transportation and warehousing; government administration, defense and compulsory social security schemes; categories of education services; categories of health services and social activities; and other service categories. The result of growth ratio (MRP) shows that the sector with the highest average regional growth rate (RPS) in Maluku province is mining and quarrying sector. Furthermore, overlay analysis shows that the sectors of government administration, defense, compulsory social security and large and retail trade; car and motorcycle repairs
\end{abstract}

Key Words: Regional Economic Development in Maluku Province, Location Quotient (LQ), Growth Ratio Model (MRP), Overlay analysis

JEL Classification: O11, O21

\section{PENDAHULUAN}

Provinsi Maluku merupakan wilayah gugus kepulauan yang berada di wilayah Indonesia bagian timur. Sebagaimana karakteristik wilayah kepulauan, lebih dari $90 \%$ wilayah kedua provinsi tersebut terdiri dari perairan, hanya sebagian kecil saja daratan dari total wilayah yang ada, dan tidak seluruh pulau dapat dihuni oleh penduduk. Tersebarnya lokasi antar pulau yang menyebar menyebabkan rendahnya akses antar gugus pulau, sehingga rentang kendali menjadi lebih jauh jangkauannya dan menjadi tantangan fisik tersendiri bagi pengembangan infrastruktur. Oleh karena itu, kualitas dan kuantitas infrastruktur yang memadai akan memberikan dampak yang positif sebagai sumber pertumbuhan ekonomi yang berkelanjutan. Oleh karena itu, adanya percepatan program pembangunan infrastruktur, mulai dari pembangunan infrastruktur jalan, jembatan, pelabuhan, sampai dengan bandara diharapkan dapat meminimalkan biaya transaksi dan secara tidak langsung dapat menggerakkan perekonomian di seluruh daerah di Maluku secara lebih merata. Sementara itu, adanya pengembangan sektor parawisata diharapkan dapat memberikan dampak positif terhadap kinerja perekonomian dan kesejahteraan masyarakat di Provinsi Maluku. Hal tersebut dikarenakan dapat mencipkan lapangan pekerjaan sehingga masyarakat dapat memperoleh pendapatan dengan semakin meningkatnya peran sektor parawisata tersebut.

Namun demikian, pengembangan perikanan kelautan dan wisata yang ditunjang oleh infrastruktur tidak dapat berjalan dengan baik apabila tidak didukung oleh peningkatan kualitas 
sumber daya manusia di Provinsi Maluku, terlebih jika dikaitkan dengan percepatan pengembangan sektor migas di Blok Masela. Oleh karena itu, adanya sumber daya manusia yang terampil akan sangat dibutuhkan, baik melalui pendidikan dan pelatihan vokasional yang sesuai dengan arah pengembangan potensi daerah sehingga Provinsi Maluku dapat memiliki tenaga kerja yang terampil dan kompetitif. Selain itu, tenaga kerja yang berkualitas tidak dapat dilepaskan dari tingkat kesehatan yang lebih baik. Dengan demikian, adanya perbaikan fasilitas kesehatan sangat penting karena dengan memiliki kesehatan yang baik maka dapat meningkatkan produktivitas masyarakat di Provinsi Maluku dalam melakukan aktivitas ekonomi.

Pada tahun 2017, PDRB di provinsi Maluku dari sisi permintaan masih ditopang oleh tingginya tingkat konsumsi rumah tangga. Penguatan konsumsi rumahtangga tersebut antara lain dipengaruhi oleh adanya peningkatan penghasilan dengan adanya pemberian Tunjangan Hari Raya (THR) untuk Pegawai Negeri Sipil (PNS) dan pegawai swasta pada bulan Juni 2017. Peningkatan pendapatan juga mengalami peningkatan sejalan dengan menguatnya Nilai Tukar Petani (NTP) karena Indeks Terima yang diperoleh oleh petani lebih baik dibandingkan dengan Indeks Bayar yang dikeluarkan oleh petani. Penguatan NTP juga terjadi pada NTT Tanaman Bahan Ma- kanan, NTP perkebunan dan NTP peternakan. Dengan demikian, berbagai hal tersebut mendorong masyarakat untuk melakukan konsumsi lebih tinggi, terlebih pada momen hari raya idul fitri yang bertepatan dengan libur anak sekolah.

Sementara itu, PDRB dari sisi lapangan usaha, kinerja pertanian, kehutanan dan perikanan sebagai salah satu kategori utama tumbuh melambat. Melambatnya pertumbuhan ini disebabkan oleh kinerja pada subsektor perikanan karena dampak dari cuaca ekstrem yang menghambat kegiatan penangkapan ikan nelayan. Namun, untuk waktu ke depan sektor pertanian dan perikanan diperkirakan akan cukup tumbuh seiring dengan semakin membaiknya cuaca yang berdampak pada semakin tingginya produktivitas hasil tangkapan ikan.

Sektor utama yang memberikan kontribusi utama adalah pertanian, kehutanan dan perikanan. Hal ini tidak lain karena adanya peningkatan dari 5,2 triliun pada tahun 2012 menjadi sekitar 6,2 triliun di tahun 2016. Meskipun begitu, berdasarkan laju pertumbuhannya justru terlihat fluktuatif dengan pertumbuhan 2012 sebesar 6,23 persen, tapi pada tahun 2016 menurun menjadi 4,82. Selama lima tahun, pertumbuhan di tahun 2012 adalah yang tertinggi dan yang terendah ada pada tahun 2015, yang hanya sebesar 1,25 persen. Lebih jelasnya dapat dilihat pada Tabel 1.

Tabel 1. PDRB Provinsi Maluku Berdasarkan Harga Konstan Menurut Lapangan Usaha (Miliar Rupiah)

\begin{tabular}{|c|l|c|c|c|c|c|}
\hline & \multicolumn{1}{|c|}{ Lapangan Usaha } & $\mathbf{2 0 1 2}$ & $\mathbf{2 0 1 3}$ & $\mathbf{2 0 1 4}$ & $\mathbf{2 0 1 5}$ & $\mathbf{2 0 1 6}^{\text {*** }}$ \\
\hline (1) & \multicolumn{1}{|c|}{$(2)$} & $(3)$ & $(4)$ & $(5)$ & $(6)$ & $(7)$ \\
\hline A & $\begin{array}{l}\text { Pertanian, Kehutanan, } \\
\text { dan Perikanan }\end{array}$ & $5.282,61$ & $5.500,92$ & $5.835,44$ & $5.908,22$ & $6.192,71$ \\
\hline B & $\begin{array}{l}\text { Pertambangan dan } \\
\text { Penggalian }\end{array}$ & 663,46 & 674,43 & 819,22 & 811,27 & 842,97 \\
\hline C & Industri Pengolahan & $1.121,18$ & $1.186,17$ & $1.286,06$ & $1.336,32$ & $1.430,36$ \\
\hline D & $\begin{array}{l}\text { Pengadaan Listrik dan } \\
\text { Gas }\end{array}$ & 18,03 & 18,72 & 25,65 & 26,99 & 29,24 \\
\hline E & Pengadaan Air, & 109,01 & 112,26 & 118,82 & 119,48 & 124,34 \\
\hline
\end{tabular}




\begin{tabular}{|c|c|c|c|c|c|c|}
\hline & Lapangan Usaha & 2012 & 2013 & 2014 & 2015 & $\left.2016^{* *}\right)$ \\
\hline & $\begin{array}{l}\text { Pengelolaan Sampah } \\
\text { dan Daur Ulang }\end{array}$ & & & & & \\
\hline $\mathrm{F}$ & Konstruksi & $1.403,27$ & $1.511,83$ & $1.622,35$ & $1.712,13$ & $1.797,42$ \\
\hline G & $\begin{array}{l}\text { Perdagangan Besar, } \\
\text { Eceran, Reparasi Mobil, } \\
\text { Motor }\end{array}$ & $2.976,30$ & $3.198,28$ & $3.327,58$ & $3.564,80$ & $3.776,00$ \\
\hline $\mathrm{H}$ & $\begin{array}{l}\text { Transportasi dan } \\
\text { Pergudangan }\end{array}$ & $1.118,33$ & $1.191,63$ & $1.295,79$ & $1.361,61$ & $1.418,65$ \\
\hline $\mathrm{I}$ & $\begin{array}{l}\text { Penyediaan Ako- } \\
\text { modasi dan Makan } \\
\text { Minum }\end{array}$ & 373,90 & 404,59 & 423,52 & 456,30 & 455,15 \\
\hline $\mathrm{J}$ & $\begin{array}{l}\text { Informasi dan Komu- } \\
\text { nikasi }\end{array}$ & 766,10 & 836,24 & 899,97 & 981,13 & $1.058,79$ \\
\hline K & $\begin{array}{l}\text { Jasa Keuangan dan } \\
\text { Asuransi }\end{array}$ & 738,22 & 810,02 & 861,68 & 924,51 & $1.009,71$ \\
\hline $\mathrm{L}$ & Real Estate & 76,98 & 79,08 & 84,69 & 87,09 & 89,06 \\
\hline $\begin{array}{l}\mathrm{M}, \\
\mathrm{N}\end{array}$ & Jasa Perusahaan & 225,69 & 238,64 & 250,16 & 258,71 & 264,38 \\
\hline $\mathrm{O}$ & $\begin{array}{l}\text { Administrasi } \\
\text { Pemerintahan, Per- } \\
\text { tahanan dan Jaminan } \\
\text { Sosial Wajib }\end{array}$ & $4.116,34$ & $4.285,73$ & $4.519,31$ & $4.969,72$ & $5.298,92$ \\
\hline $\mathrm{P}$ & Jasa Pendidikan & $1.122,99$ & $1.161,96$ & $1.272,53$ & $1.372,33$ & $1.481,77$ \\
\hline Q & $\begin{array}{l}\text { Jasa Kesehatan dan } \\
\text { Kegiatan Sosial }\end{array}$ & 502,86 & 504,09 & 517,35 & 542,49 & 572,49 \\
\hline $\begin{array}{l}\mathrm{R}, \\
\mathrm{S}, \\
\mathrm{T}, \\
\mathrm{U}\end{array}$ & Jasa Lainnya & 384,81 & 386,34 & 407,61 & 425,97 & 449,25 \\
\hline & PDRB & $21.000,08$ & $22.100,94$ & $23.567,73$ & $24.859,06$ & $26.291,19$ \\
\hline
\end{tabular}

Keterangan:

** Angka sangat sementara

Sumber: Provinsi Maluku dalam Angka, 2016

Beberapa hal yang dapat menjelaskan feKondisi perhubungan darat, laut dan udara yang nomena tersebut yaitu dikarenakan sangat bergantungnya sektor pertanian di wilayah kepulauan dengan iklim yang ada pada waktu tersebut. Pembangunan infrastruktur yang masih jauh dari harapan untuk dapat mendukung pertumbuhan sektor pertanian menjadi kendala utama. mengkoneksikan wilayah antar kabupaten/kota di provinsi Maluku masih sangat sullit untuk maju. Gravitasi aktivitas ekonomi juga masih belum berhasil untuk dikembangkan menjadi sebuah daya tarik investasi yang lebih memberikan teknologi yang lebih baik dalam hal on- farm dan 
out-farm. Konvensionalisme dalam sektor pertanian karenanya masih mendominasi perkembangan sektor ini.

Salah satu upaya yang dapat dilakukan adalah melihat berbagai potensi yang dimiliki oleh suatu daerah tersebut. Dengan demikian, apabila potensi tersebut dikembangkan dengan optimal maka secara tidak langsung akan memiliki benefit untuk daerah tersebut.

Beberapa penelitian yang berkaitan dengan penentuan potensi sektor unggulan daerah telah dilakukan. Penelitian yang dilakukan oleh Adhitama yang berjudul "Pengembangan SektorSektor Ekonomi di Tiap Kecamatan di Kabupaten Magelang". Dalam penelitiannya itu menggunakan metode analisis Location Quotient (LQ), Shift Share dan Klassen Tipologi pendekatan sektoral. Hasil penelitiannya adalah sektor jasa, sektor pertanian, dan sektor perdagangan, hotel dan restoran di Kabupaten Magelang mendominasi sektor unggulan yang ada di tiap Kecamatan di Kabupaten Magelang. Tercatat terdapat 9 kecamatan yang memiliki sektor unggulan disektor jasa, 8 kecamatan yang memiliki keunggulan disektor pertanian dan 7 kecamatan yang memiliki keunggulan disektor perdagangan, hotel dan restoran.

Basuki dan Gayatri yang berjudul "Penentu Sektor Unggulan dalam Pembangunan Daerah: Studi Kasus di Kabupaten Ogan Komering Ilir". Penelitian ini menggunakan pendekatan analisis MRP, Shift Share, LQ dan Tipologi Overlay dan Klassen. Hasil dari penelitian ini dapat disimpulkan bahwa potensi ekonomi yang dimiliki Kabupaten Ogan Komering Ilir adalah sektor pertanian dan industri manufaktur yang merupakan pertumbuhan sektor dominan. Selain itu, sektor ini juga menunjukkan peningkatan struktur pertumbuhan ekonomi. Hal ini mengingat sebagian besar penduduk diwilayah kabupaten OKI masih terlibat dalam pertanian, sehingga pertanian memiliki pertumbuhan yang luar biasa dibandingkan sektor ekonomi lainnya. Selain itu, industri manufaktur juga merupakan sektor ekonomi dengan dengan pertumbuhan yang luar biasa. Industri manufaktur ini diantaranya industri kemplang dan pempek yang banyak berkembang di provinsi Sumatera Selatan dan Kabupaten OKI.

Penelitian yang dilakukan oleh Setyorini dan Setyawati dengan judul "Identifikasi Pengembangan Wilayah Kabupaten-Kabupaten Anggota Lembaga Regional Barlingmascakeb". Penelitian ini menggunakan analisis Tipologi Klassen, analisis model rasio pertumbuhan (MRP), analisis location quotient (LQ), analisis Indeks Divergensi Krugman dan analisis Connectivity Quotient (CQ). Temuan dari penelitian ini yaitu Kabupaten Cilacap yang termasuk dalam klasifikasi daerah cepat maju dan cepat tumbuh. Kabupaten Purbalingga termasuk dalam daerah berkembang cepat. Kabupaten Banjarnegara, Kabupaten Banyumas dan Kabupaten Kebumen termasuk dalam klasifikasi daerah relatif tertinggal.

Gunawan (2011) menganalisis sektor-sektor unggulan perekonomian Kabupaten Rembang tahun 2000-2008. Penelitian ini menggunakan metode shift share, MRP, location quotient, overlay dan forecasting untuk menganalisis pertumbuhan sektor ekonomi, sektor unggulan, dan peramalan perekonomian. Hasil penelitiannya berdasarkan analisis overlay (paparan dari analisis pergeseran bersih, analisis MRP dan analisis LQ) sektor perekonominan Kabupaten Rembang yang tumbuh dominan, kompetitif dan surplus adalah sektor pertambangan dan penggalian.

Marlina (2014) menganalisis sektor unggulan dalam perekonomian Kota Bogor (periode 2006-2012). Penelitiannya menggunakan metode location quotient, shift share, MRP, dan overlay untuk melihat sektor unggulan di Kota Bogor. Hasil penelitiannya berdasarkan analisis overlay terdapat satu sektor unggulan dalam perekonomian Kota Bogor, yaitu sektor listrik, gas 
dan air bersih. Peningkatan kegiatan konstruksi, industri dan niaga di Kota Bogor mempengaruhi pertumbuhan sektor listrik, gas dan air bersih. Sementara dari sisi subsektor, terdapat tiga subsektor unggulan, yaitu subsektor air bersih, subsektor lembaga keuangan selain bank, dan subsektor sewa bangunan. Subsektor unggulan memiliki sifat komoditas tumbuh dominan, kompetitif dan surplus.

Dengan mengoptimalkan kegiatan ekonomi pada sektor potensial, diharapkan sektor tersebut akan berkembang dan dapat menjadi sektor basis pada daerah tersebut. Dengan bertambahnya kegiatan ekonomi disektor basis maupun sektor potensial daerah akan berimbas pada peningkatan PDRB. Hal ini dikarenakan dengan adanya spesialisasi sesuai dengan sektor atau subsektor unggulan yang dimiliki masing-masing daerah nantinya akan dapat digunakan untuk meningkatkan efektifitas dan efisiensi masyarakat dalam melaksanakan kegiatan ekonomi. Untuk itulah pemerintah daerah harus mengetahui dengan pasti apa saja yang merupakan sektor basis maupun sektor non basis serta sektor-sektor mana sajakah yang memiliki potensi untuk dikembangkan sehingga nantinya sektor potensial tersebut dapat menjadi sektor basis yang baru di daerah tersebut. Oleh karena itu, melihat berbagai permasalahan yang terjadi di Provinsi Maluku, terutama dari sisi lapangan usaha atau sektor maka tujuan penelitian ini adalah menganalisa potensi-potensi sektor unggulan sehingga dapat diketahui secara keseluruhan bentuk struktur ekonomi yang ada di Provinsi Maluku.

\section{METODE PENELITIAN}

Metodologi yang akan digunakan adalah Location Quotient (LQ), Model Rasio Pertumbuhan (MRP) dan analisis Overlay. Alat analisis tersebut bertujuan untuk mengetahui sektor unggulan dan struktur ekonomi yang ada pada seluruh provinsi di Pulau Maluku, sehingga dapat diketahui secara keseluruhan seperti apa struktur ekonomi yang ada di Provinsi Maluku.

Analisis Location Quotient

Analisis Location Quotient (LQ) merupakan suatu metode statistik yang menggunakan karakteristik output/nilai tambah atau kesempatan kerja untuk menganalisis dan menentukan keberagaman dari basis ekonomi (economic base) masyarakat daerah/lokal (Arsyad, 1999). Sementara itu yang termasuk kedalam basis ekonomi masyarakat adalah sektor-sektor yang memiliki karakteristik menyangkut tentang pendapatan dan kesempatan kerja. Analisis LQ memberikan kerangka pengertian tentang stabilitas dan fleksibilitas perekonomian masyarakat untuk merubah kondisi melalui penyelidikan terhadap derajat industri-industri/sektor-sektor yang ada dilingkungan masyarakat (Heilbrun, 1987).

Analisis LQ sering digunakan untuk mengestimasi industri ekspor atau basic industry, dimana industri tersebut memiliki karakteristik dapat membawa sejumlah unit uang kepada masyarakat melalui ekspor barang dan jasa, industri yang seperti ini kemudian dikenal dengan nama industri-industri basis (basic industries). Sementara itu industri-industri yang bergerak men-supply barang dan jasa untuk kegunaan konsumsi lokal/daerah dinamakan sebagai industri-industri non basis.

Seperti yang telah diketahui di atas bahwa pada dasarnya teori basis ekonomi menekankan pada berbagai aktivitas ekspor (basis) yang akan mendorong perekonomian dan aktivitas ekonomi daerah bergantung pada pertumbuhan (atau pengurangan) dari aktivitas ekspor tersebut. Asumsi yang digunakan pada saat menganalisis dengan alat ini adalah bahwa:

- Semua penduduk di setiap daerah mempunyai pola permintaaan yang sama dengan pola permintaan nasional (daerah referensinya), kondisi ini mengasumsikan bahwa 
pola pengeluaran secara geografis adalah sama

- Bahwa produktivitas tenaga kerja di seluruh daerah sama

- Setiap industri/sektor akan menghasilkan produk yang homogen

Analisis LQ pada industri/sektor tertentu membandingkan share industri/sector tertentu terhadap total tenaga kerja/ouput pada tingkat daerah/lokal dengan share industri/sektor yang sama terhadap total tenaga kerja/output pada tingkat nasional (daerah yang lebih luas, yang disebut dengan daerah referensi). Dimana jika share industri/sektor daerah lebih besar dari pada share industri/sektor nasional maka porsi kelebihan dari output/tenaga kerja tersebut dapat menjelaskan tentang besarnya ekspor yang terjadi. Pernyataan tersebut dapat dirumuskan sebagai berikut:

$$
\mathrm{LQ}_{\mathrm{i}}=\frac{\mathrm{v}_{\mathrm{i}} / \mathrm{v}_{\mathrm{t}}}{\mathrm{V}_{\mathrm{i}} / \mathrm{v}_{\mathrm{t}}}
$$

Dimana:

- LQi meyatakan besarnya nilai location quotient sektor i di suatu daerah

- vi menyatakan jumlah output/tenaga kerja dari industri i di suatu daerah

- vt menyatakan jumlah total output/tenaga kerja yang ada di suatu daerah

- vi menyatakan jumlah output/tenaga kerja dari industri i di wilayah referensi

- vt menyatakan jumlah total output/tenaga kerja yang ada di wilayah referensi

Nilai yang ditunjukkan pada rumusan LQ ini akan memiliki arti seperti pada aturan dibawah ini :

- Jika nilai LQi > 1 maka sektor i di daerah tersebut lebih terspesialisasi dibandingkan dengan sektor yang sama pada wilayah referensi atau dengan kata lain sektor tersebut merupakan sektor yang mampu untuk mengekspor produknya/tenaga kerjanya (sektor basis)

- Jika nilai LQi < 1 maka sektor i di daerah tersebut kurang terspesialisasi dibandingkan dengan sektor yang sama pada wilayah referensi atau dengan kata lain sektor tersebut merupakan sektor yang tidak mampu untuk mengekspor produknya/tenaga kerjanya (sektor non basis)

- Jika nilai LQi = 1 maka sektor i di daerah tersebut memiliki tingkat spesialisasi yang sama dibandingkan dengan sektor yang sama pada wilayah referensi atau dengan kata lain sektor tersebut merupakan sektor mampu memenuhi kebutuhan daerahnya sendiri

Model Rasio Pertumbuhan (MRP)

Selain alat analisis LQ yang digunakan untuk mengidentifikasi kategori dan subkategori ekonomi potensial berdasarkan kriteria kontribusi PDRB, alat analisis lain dirasakan penting dipergunakan untuk mengidentifikasi potensi ekonomi di Provinsi Maluku. Dalam hal ini adalah menggunakan lebih dari satu alat analisis dalam mengidentifikasi kategori ekonomi potensial di suatu wilayah. Oleh karena itu, analisis MRP turut digunakan untuk menganalisis kategori dan subkategori ekonomi potensial berdasarkan kriteria pertumbuhan PDRB Provinsi Maluku. Model rasio pertumbuhan ini digunakan untuk melihat diskripsi dari kegiatan ekonomi, terutama struktur ekonomi daerah penelitian, yang lebih menekankan pada kriteria pertumbuhan (Basuki \& Gayatri, 2009).

Model rasio pertumbuhan (dapat digunakan untuk menentukan sektor ataupun subsektor unggulan berdasarkan pertumbuhan PDRB. Model analisis ini menggunakan perbandingan pertumbuhan suatu sektor atau subsektor dalam skala kecil mapuan skala yang lebih besar. Dalam analisi MRP terdapat dua macam rasio pertumbuhan, yaitu (Tarigan, 2005):

a) Rasio Pertumbuhan Wilayah Referensi (RPr) 
Merupakan perbandingan rata-rata pertumbuhan pendapatan (PDRB) kategori i di Indonesia dengan rata-rata pertumbuhan pendapatan (PDRB) di Indonesia, dengan rumus:

$$
\begin{aligned}
& C_{i j}=\left[\begin{array}{ll}
\frac{E_{i j}}{E_{i j}} & \frac{E_{i n}}{E_{i n}}
\end{array}\right] E_{i j} \\
& C_{i j}=E_{i n} \frac{E_{i n} E_{i j}}{E_{i n}} \\
& C_{i j}=\left[\begin{array}{cc}
\frac{E_{i j} E_{i n}}{E_{i n}} & E_{i j}
\end{array}\right] \frac{E_{i n} E_{i j}}{E_{i n}} \\
& \frac{E_{i n} C_{i j}}{E_{i n} E_{i j}}+1=\frac{E_{i j} E_{n}}{E_{i n}} E_{i j}=\frac{\frac{E_{i j}}{E_{i j}}}{\frac{E_{i n}}{E_{i n}}}
\end{aligned}
$$

Rasio pertumbuhan wilayah referensi (RPr) $=\frac{\frac{E_{i n}}{E_{i n}}}{\frac{E_{n}}{E_{n}}}$

b) Rasio Pertumbuhan Wilayah Studi (RPs)

Merupakan perbandingan antara pertumbuhan pendapatan (PDRB) kategori i di Provinsi Maluku dengan pertumbuhan pendapatan (PDRB) kategori i di Provinsi Maluku, dengan rumus:

$$
\begin{aligned}
& M_{i j}=\left[\begin{array}{ll}
\frac{E_{i n}}{E_{i n}} & \frac{E_{n}}{E_{n}}
\end{array}\right] E_{i j} \\
& \frac{M_{i j}}{E_{i j}}=\left[\begin{array}{ll}
\frac{E_{i n} E_{n}}{E_{i n} E_{n}} & \frac{E_{n} E_{i n}}{E_{i n} E_{n}}
\end{array}\right] \\
& \frac{M_{i j}}{E_{i j}}=\left[\begin{array}{ll}
\frac{E_{i n} E_{n}}{E_{i n}} & 1
\end{array}\right] \frac{E_{n}}{E_{n}} \\
& \frac{E_{i n} C_{i j}}{E_{i n} E_{i j}}+1=\frac{E_{i j} E_{n}}{E_{i n}} E_{i j}=\frac{\frac{E_{i j}}{E_{i j}}}{\frac{E_{i n}}{E_{i n}}}
\end{aligned}
$$

Rasio pertumbuhan wilayah referensi (RPs) $=\frac{\frac{E_{i j}}{E_{i j}}}{\frac{E_{i n}}{E_{i n}}}$

Dimana:

Keterangan:

- $\Delta$ Eij $=$ Perubahan PDRB kategori (subkategori) i di Provinsi Maluku

- Eij,t = PDRB kategori (subkategori) i di Provinsi Maluku pada tahun akhir analisis
- $\Delta$ Ein $=$ Perubahan PDRB kategori (subkategori) i di Indonesia

- Ein,t = PDRB kategori (subkategori) i di Indonesia pada tahun akhir analisis

- $\Delta \mathrm{En} \quad=$ Perubahan PDRB Indonesia

- $\mathrm{En}, \mathrm{t} \quad=$ Total PDRB tahun akhir analisis di Indonesia

- $\mathrm{Mij}=$ Perubahan PDRB kategori (subkategori) i di Provinsi Maluku yang disebabkan oleh pengaruh pertumbuhan kategori (subkategori) i di Indonesia

- $\mathrm{Cij}=$ Perubahan PDRB kategori (subkategori) i di Provinsi Maluku yang disebabkan oleh keunggulan kompetitif kategori (subkategori) i di Provinsi Maluku.

Berdasarkan rumus atau rasio yang telah disampaikan di atas, maka terdapat 4 kategori dalam model rasio pertumbuhan, atara lain:

(1) RPs dan RPr memiliki nilai (+), berarti kegiatan tersebut pada tingkat wilayah referensi maupun tingkat wilayah studi pertumbuhannya menonjol.

(2) Nilai RPs (+) dan $R P r(-)$, berarti kegiatan tersebut pada tingkat wilayah referensi pertumbuhannya menonjol dan pada tingkat wilayah studi pertumbuhannya belum menonjol.

(3) Nilai RPs (-) dan RPr (+), berarti kegiatan tersbut pada tingkat wilayah referensi pertumbuhannya belum menonjol dan pada tingkat wilayah studi pertumbuhannya menonjol.

(4) RPs dan RPr memiliki nilai (-), berati kegiatan tersebut pada tingkat wilayah referensi maupun wilayah studi pertumbuhannya belum menonjol.

Analisis Overlay

Setelah melakukan perhitungan menggunakan analisis LQ dan MRP, maka berikutnya adalah melakukan overlay data antara hasil analisis LQ dengan analisis MRP. Teknik overlay ini menggunakan hasil perhitungan RPs (pertumbuhan) dan LQ (kontribusi), hasil dari 
analisis ini digunakan untuk melihat deskripsi sektor ekonomi yang potensial untuk dikembangkan (Kuncoro, 2004). Hasil analisis ini diklasifikasikan menjadi 4 tipe, yaitu:

(1) RPs dan LQ memiliki nilai (+), menunjukkan sektor ekonomi tersebut dominan baik pertumbuhan maupun kontribusinya.

(2) RPs (+) dan LQ (-), menunjukkan jika sektor ekonomi tersebut dominan dalam pertumbuhan namun kontribusinya kecil.

(3) RPs (-) dan LQ (+), menunjukkan jika sektor ekonomi tersebut memiliki pertumbuhan yang kecil namun memiliki nilai kontribusi yang besar.

(4) RPs dan LQ memiliki nilai (-), menunjukkan bahwa sektor ekonomi tersebut memiliki nilai kecil baik dalam pertumbuhan maupun kontribusinya.

\section{HASIL DAN PEMBAHASAN}

Efisiensi Badan Usaha Milik Daerah (BUMD) bidang jasa produksi, merupakan salah satu indikator dalam mengukur capaian kinerja BUMD bidang jasa produksi yang dimiliki oleh pemerintah Provinsi Jawa Tengah. Kinerja BUMD bidang jasa produksi dinyatakan efisien apabila angka rasio efisiensi faktor input dan output sama dengan 1 atau (100\%), sementara jika nilai efisiensi mendekati 0 dan atau kurang dari 1 ( $\mathrm{E}<1$ atau $\mathrm{E}<100 \%$ ), maka dapat diartikan BUMD bidang jasa produksi tersebut tidak efisien.

Dalam melihat potensi ekonomi di Provinsi Maluku maka dilakukan indentifikasi dan analisis terhadap kategori atau subkategori ekonomi yang potensial di Provinsi Maluku dan digunakan 4 macam alat analisis, yaitu Analisis Location Quotient (LQ), Analisis Model Rasio Pertumbuhan (MRP), Analisis Overlay dan ANP. Secara lebih rinci pembahasan melalui keempat alat analisis tersebut akan dijelaskan berikut ini.
Analisis Location Quotient

Alat analisis Location Quotient (LQ) digunakan untuk mengidentifikasi keunggulan komparatif kegiatan ekonomi (biasa disebut sebagai sektor basis) di Provinsi Maluku dengan membandingkannya terhadap Nasional. Berdasarkan analisis LQ sebagaimana yang tertera pada Tabel 1 maka Provinsi Maluku terdapat 8 kategori ekonomi yang memiliki keunggulan komparatif (nilai LQ-nya > 1), yaitu kategori pertanian, kehutanan dan perikanan; kategori pengadaan air, pengelolaan sampah dan daur ulang; kategori perdagangan besar-eceran dan reparasi mobil-sepeda motor; kategori transportasi dan pergudangan; katgori adminstrasi pemerintahan, pertahanan dan jaminan sosial wajib; kategori jasa pendidikan; kategori jasa kesehatan dan kegiatan sosial; dan kategori jasa lainnya.

Pada kategori pertanian, kehutanan dan perikanan terlihat bahwa nilai LQ-nya mengalami trend penurunan. Hal ini disebabkan diberlakukanya moratorium perikanan sehingga mengakibatkan penurunan pada sub kategori perikanan yang berdampak langsung terhadap kategori ini; selanjutnya pada subategori kehutanan menurunnya aktifitas ilegal loging akibat pengawasan yang ketat dari pemerintah dan aparat keamanan cenderung memberikan penurunan produksi pada subkategori ini yang bersumber dari hasil ilegal loging. Selama periode 2010-2016, untuk beberapa tahun terakhir (2013-2014) efek El-nino menjadi penyebab kekeringan yang berkepanjangan sehingga terjadi gagal panen untuk komoditi tanaman pangan dan hortikultura di beberapa kabupaten yang merupakan sentral pertanian di Provinsi Maluku sehingga tidak langsung menurukan produksi sub kategori ini. Adanya Fenomena Gunung Botak pada tahun 2013-2014 banyak lahan pertanian di Kabupaten Buru yang tidak difungsikan dikarenakan tenaga kerja pertanian beralih fungsi menjadi penambang emas pada areal Gunung Botak. 
Tabel 2. Hasil Penghitungan Location Quotient (LQ)

Provinsi Maluku Tahun 2010 - 2016

\begin{tabular}{|c|c|c|c|c|c|c|c|c|c|}
\hline \multirow{2}{*}{ Lapangan Usaha } & \multicolumn{7}{|c|}{ Location Quotient (LQ) } & \multirow{2}{*}{$\begin{array}{c}\text { Rata-rata } \\
\text { LQ }\end{array}$} & \multirow{2}{*}{ Hasil } \\
\hline & 2010 & 2011 & 2012 & 2013 & 2014 & 2015 & 2016 & & \\
\hline $\begin{array}{l}\text { A. Pertanian, Kehutanan dan } \\
\text { Perikanan }\end{array}$ & 1.83 & 1.82 & 1.83 & 1.83 & 1.83 & 1.76 & 1.73 & 1.80 & Basis \\
\hline $\begin{array}{l}\text { B. Pertambangan dan Peng- } \\
\text { galian }\end{array}$ & 0.29 & 0.32 & 0.31 & 0.31 & 0.36 & 0.38 & 0.39 & 0.34 & $\begin{array}{l}\text { Non Ba- } \\
\text { sis }\end{array}$ \\
\hline C. Industri Pengolahan & 0.24 & 0.24 & 0.24 & 0.24 & 0.25 & 0.24 & 0.24 & 0.24 & $\begin{array}{l}\text { Non Ba- } \\
\text { sis }\end{array}$ \\
\hline D. Pengadaan Listrik dan Gas & 0.08 & 0.08 & 0.08 & 0.08 & 0.09 & 0.09 & 0.09 & 0.08 & $\begin{array}{l}\text { Non Ba- } \\
\text { sis }\end{array}$ \\
\hline $\begin{array}{l}\text { E. Pengadaan Air, Pengelolaan } \\
\text { Sampah, Limbah dan Daur } \\
\text { Ulang }\end{array}$ & 6.22 & 6.21 & 6.20 & 6.18 & 6.08 & 5.64 & 6.01 & 6.08 & Basis \\
\hline F. Konstruksi & 0.69 & 0.70 & 0.69 & 0.70 & 0.70 & 0.68 & 0.69 & 0.69 & $\begin{array}{l}\text { Non Ba- } \\
\text { sis }\end{array}$ \\
\hline $\begin{array}{l}\text { G. Perdagangan Besar dan } \\
\text { Eceran; Reparasi Mobil dan } \\
\text { Sepeda Motor }\end{array}$ & 1.00 & 0.98 & 1.00 & 1.03 & 1.00 & 1.03 & 1.05 & 1.01 & Basis \\
\hline $\begin{array}{l}\text { H. Transportasi dan } \\
\text { Pergudangan }\end{array}$ & 1.46 & 1.44 & 1.41 & 1.41 & 1.40 & 1.35 & 1.32 & 1.40 & Basis \\
\hline $\begin{array}{l}\text { I. Penyediaan Akomodasi dan } \\
\text { makan Minum }\end{array}$ & 0.59 & 0.59 & 0.59 & 0.60 & 0.58 & 0.59 & 0.57 & 0.59 & $\begin{array}{l}\text { Non Ba- } \\
\text { sis }\end{array}$ \\
\hline J. Informasi dan Komunikasi & 0.94 & 0.92 & 0.87 & 0.86 & 0.83 & 0.81 & 0.82 & 0.86 & $\begin{array}{l}\text { Non Ba- } \\
\text { sis }\end{array}$ \\
\hline $\begin{array}{l}\text { K. Jasa Keuangan dan Asur- } \\
\text { ansi }\end{array}$ & 0.86 & 0.96 & 0.95 & 0.95 & 0.96 & 0.93 & 0.94 & 0.94 & $\begin{array}{l}\text { Non Ba- } \\
\text { sis }\end{array}$ \\
\hline L. Real Estate & 0.13 & 0.13 & 0.12 & 0.12 & 0.12 & 0.11 & 0.12 & 0.12 & $\begin{array}{l}\text { Non Ba- } \\
\text { sis }\end{array}$ \\
\hline MN. Jasa Perusahaan & 0.74 & 0.72 & 0.70 & 0.68 & 0.64 & 0.61 & 0.59 & 0.67 & $\begin{array}{l}\text { Non Ba- } \\
\text { sis }\end{array}$ \\
\hline $\begin{array}{l}\text { O. Administrasi Pemerinta- } \\
\text { han, Pertahanan dan Jaminan } \\
\text { Sosial Wajib }\end{array}$ & 4.82 & 4.96 & 5.25 & 5.33 & 5.40 & 5.60 & 5.71 & 5.30 & Basis \\
\hline P. Jasa Pendidikan & 1.91 & 1.84 & 1.74 & 1.67 & 1.71 & 1.69 & 1.68 & 1.75 & Basis \\
\hline $\begin{array}{l}\text { Q. Jasa Kesehatan dan } \\
\text { Kegiatan Sosial }\end{array}$ & 2.46 & 2.38 & 2.31 & 2.14 & 2.01 & 1.94 & 1.87 & 2.16 & Basis \\
\hline RSTU. Jasa Lainnya & 1.36 & 1.26 & 1.20 & 1.13 & 1.08 & 1.03 & 0.99 & 1.15 & Basis \\
\hline
\end{tabular}

Sumber: Hasil Perhitungan 
Analisis Model Rasio Pertumbuhan

Model rasio Pertumbuhan (MRP) merupakan alat analisis yang digunakan untuk melihat potensi kategori ekonomi berdasarkan kriteria pertumbuhan. Analisis MRP terdiri dari 2 instrumen pengukuran, yaitu Rasio Pertumbuhan Wilayah Studi (RPs) yang menunjukkan rasio pertumbuhan antara wilayah studi dengan wilayah referensi yang lebih besar, dalam hal ini adalah Provinsi Maluku terhadap nasional. Selanjutnya instrumen kedua adalah Rasio Pertumbuhan Wilayah Referensi terhadap pertumbuhan ekonomi agregat pada wilayah referensi (RPr).

Pada Tabel 2 menunjukkan bahwa RPs kategori pertanian, kehutanan dan perikanan di Provinsi Maluku memiliki nilai kurang dari 1. Kondisi ini mengindikasikan bahwa kategori pertanian, kehutanan dan perikanan bukan merupakan kegiatan ekonomi yang potensial di Provinsi Maluku berdasarkan kriteria pertumbuhan. Sementara itu, untuk tingkat Nasional kategori pertanian, kehutanan dan perikanan juga bukan merupakan kategori potensial karena memiliki nilai RPr yang kurang dari 1.

Kategori pertambangan dan penggalian di Provinsi Maluku ternyata memiliki nilai RPs lebih dari 1. Artinya, kategori pertambangan dan penggalian merupakan kategori potensial berdasarkan kriteria pertumbuhan. Kondisi yang berbeda terlihat di tingkat Nasional, karena nilai RPr kategori pertambangan dan penggalian menunjukkan nilai kurang dari 1. Dengan demikian, kategori pertambangan dan penggalian secara keseluruhan di Indonesia kurang potensial dari sisi pertumbuhannya akan tetapi di Provinsi Maluku kategori ini merupakan kategori potensial berdasarkan kriteria pertumbuhannya. Selanjutnya, kategori Industri pengolahan merupakan kategori potensial di Provinsi Maluku dengan nilai RPs lebih dari 1 (RPs $=1,21)$, namun untuk hasil penghitungan RPr Nasional kategori indus- tri pengolahan masih kurang potensial dikarenakan nilai $R P r$ kurang dari $1(\operatorname{RPr}=0,97)$.

Kategori pengadaan listrik dan gas merupakan kategori potensial di Provinsi Maluku dengan hasil penghitungan RPs lebih dari 1 (RPs $=2,14)$. Kategori ini juga merupakan kategori potensial untuk secara keseluruhan di indonesia, dikarenakan nilai RPr adalah sebesar 1,07. Jika dilihat dari subkategori pembentuknya, subkategori Ketenagalistrikan lebih dominan dan sangat potensial, hal ini dapat ditunjukkan dengan nilai RPs dan RPr yang lebih besar dari 1. Sementara itu, kategori pengadan air, pengelolaan sampah, limbah dan daur ulang di Provinsi Maluku kurang potensial $(\mathrm{RPs}=0,76)$ dari sisi pertumbuhan, begitu juga pertumbuhan kategori ini pada level nasional dimana terlihat kurang berpotensi dengan nilai RPr adalah sebesar 0,94.

Kategori konstruksi di Provinsi Mauku merupkan kategori yang sangat potensial $(\mathrm{RPs}=$ 1,11) dari sisi pertumbuhan, begitu juga dengan pertumbuhan kategori konstruksi di Indonesia juga merupakan kategori yang potensial dengan nilai $\operatorname{RPr}$ adalah sebesar 1,40. Untuk kategori perdagangan besar-eceran dan reparasi mobilsepeda motor juga sangat berpotensi di Provinsi Maluku dengan nilai RPs adalah sebesar 1,36. Selanjutnya kategori transportasi dan pergudangan di Provinsi Maluku kurang berpotensi dimana nilai RPs-nya adalah sebesar 0,92 . Sementara untuk nasional, kategori transportasi dan pergudangan sangat potensial dapat dilihat dengan nilai RPr adalah sebesar 1,45.

Kategori penyediaan akomodasi dan makan minum di Provinsi Maluku merupakan kategori potensial (RPs $=1,21)$. Pada level nasional kategori ini juga perupakan kategori potensial, hal ini terlihat pada nilai RPr adalah sebesar 1,19. Untuk kategori informasi dan komunikasi di Provinsi Maluku kurang potensial terlihat dari nilai RPs yaitu sebesar 0,78 ; sedangkan pada level nasional pertumbuhan kategori informasi dan 
komunikasi merupakan kategori yang sangat potensial dengan nilai RPr adalah sebesar 2,12. Kategori real estate kurang potensial di Provinsi Maluku (RPs=0,67), sedangkan pada level nasional kategori ini potensial. Hal ini dapat dilihat dari besarnya nilai $\mathrm{RPr}$ yang lebih besar dari $1(\mathrm{RPr}=$ 1,23).

Pada kategori jasa perusahaan di Provinsi Maluku tidak begitu potensial dapat dilihat dari besarnya nilai RPs adalah sebesar 0,62; sedangkan untuk tingkat nasional kategori ini sangat potensial, hal ini dapat dilihat dengan nilia RPr-nya adalah sebesar 1,70. Sementara itu, untuk kategori administrasi pemerintahan, pertahanan dan jaminan sosial wajib di Provinsi Maluku sangat potensial, dimana hal ini terlihat dengan nilai RPsnya adalah sebesar 2,30; sebaliknya pada level nasional kategori ini kurang potensial. Hal itu terlihat dari besarnya nilai RPr adalah sebesar 0,70 .

Pada kategori jasa pendidikan, kategori jasa kesehatan dan kegiatan sosial, dan kategori jasa lainnya di Provinsi Maluku kurang begitu potensial. Hal itu dapat dilihat dari nilai RPs-nya sebesar berturut-turut adalah sebesar 0,77; 0,49 dan 0,34 . Sebaliknya pada level nasional untuk kategori jasa pendidikan; kategori jasa kesehatan dan kegiatan sosial; dan kategori jasa lainnya merupkan kategori yang potensial. Besarnya nilai RPr adalah sebagai berikut kategori jasa pendidikan 1,40; kategori jasa kesehatan dan kegiatan sosial 1,62 dan kategori jasa lainnya adalah sebesar 1,49 .

Tabel 3. Hasil Penghitungan Rasio Pertumbuhan Provinsi Maluku (RPs) dan Rasio Pertumbuhan Indonesia (RPr) Provinsi MalukuTahun 2010 - 2016

\begin{tabular}{|l|c|c|c|c|}
\hline \multirow{2}{*}{\multicolumn{1}{|c|}{ Lapangan Usaha }} & \multicolumn{2}{c|}{ RPs } & \multicolumn{2}{c|}{ RPr } \\
\cline { 2 - 5 } & Riil & Nominal & Riil & Nominal \\
\hline \multicolumn{1}{|c|}{ A. Pertanian, Kehutanan dan Perikanan } & 0.95 & - & 0.81 & - \\
\hline B. Pertambangan dan Penggalian & 7.59 & + & 0.23 & - \\
\hline C. Industri Pengolahan & 1.21 & + & 0.97 & - \\
\hline D. Pengadaan Listrik dan Gas & 2.14 & + & 1.07 & + \\
\hline $\begin{array}{l}\text { E. Pengadaan Air, Pengelolaan Sampah, } \\
\text { Limbah dan Daur Ulang }\end{array}$ & 0.76 & - & 0.94 & - \\
\hline F. Konstruksi & 1.11 & + & 1.40 & + \\
\hline $\begin{array}{l}\text { G. Perdagangan Besar dan Eceran; Repar- } \\
\text { asi Mobil dan Sepeda Motor }\end{array}$ & 1.36 & + & 1.06 & + \\
\hline H. Transportasi dan Pergudangan & 0.92 & - & 1.45 & + \\
\hline $\begin{array}{l}\text { I. Penyediaan Akomodasi dan makan Mi- } \\
\text { num }\end{array}$ & 1.21 & + & 1.19 & + \\
\hline J. Informasi dan Komunikasi & 0.78 & - & 2.22 & + \\
\hline K. Jasa Keuangan dan Asuransi & 1.45 & + & 1.54 & + \\
\hline L. Real Estate & 0.67 & - & 1.23 & + \\
\hline MN. Jasa Perusahaan & 0.62 & - & 1.70 & + \\
\hline $\begin{array}{l}\text { O. Administrasi Pemerintahan, Pertahan- } \\
\text { an dan Jaminan Sosial Wajib }\end{array}$ & 2.30 & + & 0.70 & - \\
\hline P. Jasa Pendidikan & 0.77 & - & 1.40 & + \\
\hline
\end{tabular}




\begin{tabular}{|l|c|c|c|c|}
\hline \multirow{2}{*}{ Lapangan Usaha } & \multicolumn{2}{c|}{ RPs } & \multicolumn{2}{c|}{ RPr } \\
\cline { 2 - 5 } & Riil & Nominal & Riil & Nominal \\
\hline Q. Jasa Kesehatan dan Kegiatan Sosial & 0.49 & - & 1.62 & + \\
\hline RSTU. Jasa Lainnya & 0.34 & - & 1.49 & + \\
\hline
\end{tabular}

Sumber: Hasil Perhitungan

Analisis Overlay

Analisis overlay merupakan analisis yang digunakan untuk melihat kategori dan sub kategori ekonomi potensial baik dari sisi kontribusi maupun sisi pertumbuhan PDRB. Apabila hasil analisis LQ dan MRP dibuat overlay, terdapat empat kemungkinan mengenai suatu sektor ekonomi di kabupaten yang dikaji. Pertama, apabila LQ > 1 dan RPs> RPr (untuk nilai RPs dan RPR yang lebih besar dari 1), maka sektor tersebut merupakan sektor yang sangat dominan, baik dari kontribusi maupun dari pertumbuhannya.

Sektor ini adalah sektor yang maju dan bertumbuh cepat. Sektor ini dapat dipandang sebagai sektor unggulan (leading sector) di provinsi yang dikaji. Kedua, apabila LQ $<1$ tetapi RPs > RPr (untuk nilai RPs dan RPR yang lebih besar dari 1), maka sektor tersebut merupakan sektor yang kontribusinya masih kecil tetapi pertumbuhannya semakin besar.

Sektor serupa ini adalah sektor yang sedang bertumbuh dan dapat ditingkatkan kontribusinya agar menjadi sektor yang dominan. Sektor ini dapat dipandang sebagai sektor yang potensil (potential sector) di provinsi yang dikaji. Ketiga, apabila LQ > 1 tetapi RPs < RPr maka sektor tersebut merupakan sektor yang kontribusinya besar tetapi pertumbuhannya lebih kecil. Sektor ini merupakan sektor yang sedang mengalami penurunan pertumbuhan. Sektor ini dapat dipandang sebagai sektor yang tertekan yang mengalami penurunan di provinsi yang dikaji. Keempat, apabila LQ $<1$ dan RPs $<$ RPr, maka sektor tersebut merupakan sektor yang tidak potensil baik dari kriteria kontribusi maupun kriteria pertumbuhan. Sektor ini adalah sektor yang tertinggal di provinsi yang dikaji.

Tabel 4. Analisis Overlay Potensi Ekonomi Provinsi Maluku Tahun 2010-2016

\begin{tabular}{|c|c|c|c|c|c|c|}
\hline Lapangan Usaha & RPs & RPr & LQ & \multicolumn{3}{|c|}{ Overlay } \\
\hline (1) & (2) & (3) & (4) & (5) & (6) & (7) \\
\hline A. Pertanian, Kehutanan dan Perikanan & 0.95 & 0.81 & 1.80 & - & - & + \\
\hline B. Pertambangan dan Penggalian & 7.59 & 0.23 & 0.34 & + & - & - \\
\hline C. Industri Pengolahan & 1.21 & 0.97 & 0.24 & + & - & - \\
\hline D. Pengadaan Listrik dan Gas & 2.14 & 1.07 & 0.08 & + & + & - \\
\hline $\begin{array}{l}\text { E. Pengadaan Air, Pengelolaan Sampah, } \\
\text { Limbah dan Daur Ulang }\end{array}$ & 0.76 & 0.94 & 6.08 & - & - & + \\
\hline F. Konstruksi & 1.11 & 1.40 & 0.69 & + & + & - \\
\hline $\begin{array}{l}\text { G. Perdagangan Besar dan Eceran; } \\
\text { Reparasi Mobil dan Sepeda Motor }\end{array}$ & 1.36 & 1.06 & 1.01 & + & + & + \\
\hline H. Transportasi dan Pergudangan & 0.92 & 1.45 & 1.40 & - & + & + \\
\hline $\begin{array}{l}\text { I. Penyediaan Akomodasi dan makan } \\
\text { Minum }\end{array}$ & 1.21 & 1.19 & 0.59 & + & + & - \\
\hline J. Informasi dan Komunikasi & 0.78 & 2.22 & 0.86 & - & + & - \\
\hline
\end{tabular}




\begin{tabular}{|l|c|c|c|c|c|c|}
\hline \multicolumn{1}{|c|}{ Lapangan Usaha } & RPs & RPr & \multicolumn{2}{c|}{ LQ } & \multicolumn{3}{c|}{ Overlay } \\
\hline \multicolumn{1}{|c|}{$(\mathbf{1})$} & $\mathbf{( 2 )}$ & $\mathbf{( 3 )}$ & $\mathbf{( 4 )}$ & $\mathbf{( 5 )}$ & $\mathbf{( 6 )}$ & $\mathbf{( 7 )}$ \\
\hline K. Jasa Keuangan dan Asuransi & 1.45 & 1.54 & 0.94 & + & + & - \\
\hline L. Real Estate & 0.67 & 1.23 & 0.12 & - & + & - \\
\hline MN. Jasa Perusahaan & 0.62 & 1.70 & 0.67 & - & + & - \\
\hline $\begin{array}{l}\text { O. Administrasi Pemerintahan, Per- } \\
\text { tahanan dan Jaminan Sosial Wajib }\end{array}$ & 2.30 & 0.70 & 5.30 & + & - & + \\
\hline P. Jasa Pendidikan & 0.77 & 1.40 & 1.75 & - & + & + \\
\hline Q. Jasa Kesehatan dan Kegiatan Sosial & 0.49 & 1.62 & 2.16 & - & + & + \\
\hline RSTU. Jasa Lainnya & 0.34 & 1.49 & 1.15 & - & + & + \\
\hline
\end{tabular}

Sumber: Hasil Perhitungan

Upaya untuk melihat potensi ekonomi Provinsi Maluku secara lebih komperhensif, maka analisis overlay dilakukan sehingga analisis overlay yang dipergunakan untuk melihat keunggulan dan potensi ekonomi di Provinsi Maluku ini merupakan integrasi antara analisis LQ (aspek keunggulan komparatif) dan analisis MRP (Rasio Pertumbuhan Wilayah Studi - RPs).

Hasil perhitungan analisis Overlay tahun 2010 - 2016 pada Tabel 4, dapat dilihat sektor ekonomi di Provinsi Maluku, baik pertumbuhan maupun dari kontribusi yang diklasifikasikan sebagai berikut:

1. Pertumbuhan (+) dan kontribusi (+) terdapat pada sektor administrasi pemerintahan, pertahanan, jaminan sosial wajib dan perdagangan besar dan eceran, reparasi mobil dan sepeda motor. Artinya, sektor tersebut menunjukkan suatu kegiatan yang sangat dominan baik dari pertumbuhan maupun dari kontribusi yang sangat besar terhadap pembentukan PDRB dan pembangunan di Provinsi Maluku.

2. Pertumbuhan (+) dan kontribusi (-), terdapat pada sektor pertambangan dan penggalian, industri pengolahan, pengadaan listrik dan gas, konstruksi, penyediaan akomodasi dan makan minum dan jasa keuangan, asuransi menunjukkan suatu kegiatan yang pertumbuhannya dominan tetapi kontribusinya kecil. Kegiatan ini perlu lebih ditingkatkan kontri- businya untuk menjadi kegiatan yang dominan.

3. Pertumbuhan (-) dan kontribusi (+), terdapat pada sektor pertanian, kehutanan dan perikanan, pengadaan air, pengelolaan sampah, limbah dan daur ulang, transportasi dan pergudangan, jasa pendidikan, jasa kesehatan dan kegiatan sosial dan jasa lainnya menunjukkan suatu kegiatan yang pertumbuhannya kecil tetapi kontribusinya besar. Kegiatan ini sangat memungkinkan bahwa kegiatan sedang mengalami penurunan.

4. Pertumbuhan (-) dan kontribusi (-), terdapat pada sektor informasi dan komunikasi, jasa perusahaan dan real estate menunjukkan suatu kegiatan yang tidak potensial baik dari kriteria pertumbuhan maupun kontribusi.

\section{SIMPULAN}

Ada beberapa temuan dari studi ini yang dapat disimpulkan. Pertama, dalam penelitian ini ditemukan bukti kuat bahwa Provinsi Maluku terdapat 8 kategori ekonomi yang memiliki sektor basis, yaitu kategori pertanian, kehutanan dan perikanan; kategori pengadaan air, pengelolaan sampah dan daur ulang; kategori perdagangan besar-eceran dan reparasi mobil-sepeda motor; kategori transportasi dan pergudangan; kategori adminstrasi pemerintahan, pertahanan dan jaminan sosial wajib; kategori jasa pendidikan; kat- 
egori jasa kesehatan dan kegiatan sosial; dan kategori jasa lainnya. Hasil perhitungan model rasio pertumbuhan (MRP) menunjukkan bahwa sektor yang memiliki nilai rata-rata Pertumbuhan Regional (RPs) tertinggi di provinsi Maluku yakni sektor Pertambangan dan Penggalian. Nilai ini mengindikasikan bahwa pertumbuhan dari sektor Pertambangan dan Penggalian di provinsi Malu$\mathrm{ku}$ lebih tinggi dibandingkan nasional. Selanjutnya, hasil perhitungan analisis overlay menunjukkan bahwa sektor administrasi pemerintahan, pertahanan, jaminan sosial wajib dan perdagangan besar dan eceran; reparasi mobil dan sepeda motor mrupakan kegiatan yang sangat dominan baik dari pertumbuhan maupun dari kontribusi yang sangat besar terhadap pembentukan PDRB dan pembangunan di Provinsi Maluku. Sementara itu, sektor informasi dan komunikasi, jasa perusahaan dan real estate menunjukkan suatu kegiatan yang tidak potensial, baik dari kriteria pertumbuhan maupun kontribusi.

\section{DAFTAR PUSTAKA}

Adhitama, R. 2012. “Pengembangan Sektor-Sektor Ekonomi Di Tiap Kecamatan Di Kabupaten Magelang". Economic Development Analysis Journal

Arsyad, L, 1999. Pengantar Perencanaan dan Pembangunan Ekonomi Daerah. BPFE UGM. Yogyakarta.

Basuki, A.T \& Gayatri, U. 2009. "Penentuan Sektor Unggulan dalam Pembangunan Daerah". Jurnal Ekonomi dan Studi Pembangunan, Vol 10, No.1. BPS Maluku. 2016. "Maluku Dalam Angka 2016. Badan Pusat Statistik Provinsi Maluku". Ambon

Gunawan. 2011. "Analisis Sektor-Sektor Unggulan Perekonomian Kabupaten Rembang tahun 2000-2008". Institut Pertanian Bogor.

J. Heilbrun 1987. “Urban Ecomics”, New York “St. Martin Press
Kuncoro, M. 2004. “Otonomi dan Pembangunan Daerah". Jakarta: Erlangga

Marlina, Y. 2014. “Analisis Sektor Unggulan Dalam Perekonomian Kota Bogor Periode 2006-2012". Fakultas Ekonomi dan Manajemen Institut Pertanian Bogor

Setyorini, G.D \& Gunawan., R.S. 2008. “Identifikasi Pengembangan Wilayah Kabupaten Anggota Lembaga Regional Barlingmascakeb". Jurnal Ekonomi dan Studi Pembangunan

Tarigan, R. 2005. “Ekonomi Regional (Teori dan Aplikasi)". Jakarta: PT Bumi Aksara 